\title{
Beef production from dairy bulls under two different production systems and its effect on the fatty acid profile and beef quality
}

\author{
Adrián Catrileo $^{1 *}$, Rodrigo Morales ${ }^{2}$, Claudio Rojas ${ }^{1}$, and David Cancino ${ }^{3}$
}

Bulls in dairy production are usually slaughtered at an early age to avoid production problems and unnecessary costs. However, the animals could be a source of additional income and better quality meat. The objective of this work was to determine the characteristic and quantity of fatty acids of the Longissimus thoracis muscle of dairy bulls finished at pasture and in an intensive feeding system. Sixteen 14-mo old Holstein Friesian dairy bulls with initial live weights (LW) of $340 \pm 20 \mathrm{~kg}$ were randomly assigned to bulls with daily pasture silage and kale (Brassica oleracea L.) supplements and $1.0 \%$ concentrate at pasture (T1) and bulls with pasture silage supplements and $2 \%$ concentrate in confinement (T2). No differences $(P>0.05)$ were found between treatments for dressing percentage, rib eye area, and fat cover when animals were slaughtered at 21-mo, with LW $550 \mathrm{~kg}$. However, kidney fat for T1 and T2 of 4.44 and $2.61 \mathrm{~kg}^{-1}$, respectively, were different $(P<0.05)$ as was $\mathrm{pH}$, where T2 had a higher value $(5.72)$ than T1 (5.46). Significant differences $(P<0.05)$ between treatments were found for all polyunsaturated fatty acids (PUFA), conjugated linoleic acid (CLA) $c-9, t-11$, C18:2 $n$-6 trans, C18:3 n-3, C22:5 n-3, C22:6n-3, with higher levels for T1. Beef from the forage-fed bulls (T1) had an $n-6: n-3$ ratio below 4.0 .

Key words: Beef quality, Brassica oleracea, CLA, fatty acids, Holstein Friesian bulls.

\section{INTRODUCTION}

Lean beef from beef cattle finished at pasture has a high nutrient density and is an excellent source of protein, vitamins, minerals, and essential fatty acids. Beef is a source of high quality protein. Unlike some plant sources of protein, beef supplies every essential amino acid for optimal performance. Beef is a valuable source of many minerals, including $\mathrm{Fe}, \mathrm{Zn}$, Se, and $\mathrm{Cu}$ (Pereira and Vicente, 2013). Moreover, it has low fat content (less than $5 \%$ relative to muscle) and low cholesterol content (Johnson, 2009).

Meat and milk from ruminants also represents the major dietary sources of conjugated linoleic acids (CLAs). The rumenic acid C18:2 cis-9 trans-11 (referred to as CLA) accounts for $75-90 \%$ of total CLAs in meat. Conjugated linoleic acids are associated with a number of health-promoting biological activities, including anticarcinogenic and anti-atherogenic activity, the ability to reduce the catabolic effects of immune stimulation, enhance growth and reduce body fat (Banni et al., 2002).

${ }^{1}$ Instituto de Investigaciones Agropecuarias, INIA Carillanca, P.O. Box 58-D, Temuco, Chile. "Corresponding author (acatrile@inia.cl). ${ }^{2}$ Instituto de Investigaciones Agropecuarias, INIA Remehue, Ruta 5 Norte km 8, P.O. Box 24-0, Osorno, Chile.

${ }^{3}$ Universidad Mayor, Facultad de Ciencias Silvoagropecuarias, Av. Alemania 0281, Temuco, Chile.

Received: 20 November 2013.

Accepted: 14 April 2014.

doi: $10.4067 /$ S0718-58392014000300017
Beef from cattle finished on pasture have higher CLA content than beef from cattle finished in feedlots (French et al., 2000; Schmid et al., 2006). There is now more interest in the quality of beef than factors such as growth rate and carcass composition, which had been the main focus of producers. A recent study evaluated the nutritional quality (intramuscular fat, cholesterol content, and fatty acid composition) of beef produced in Chile under different production systems classified according to the type of finishing diet (Morales et al., 2012). Information is available about consumer sensory preferences for Chilean beef from different finishing systems. In general, consumers prefer beef produced on pastures and reject beef with high visual marbling (Morales et al., 2013).

Traditionally, male calves in Chilean dairies have been sacrificed or sold at an early age to avoid difficulties in finishing and unnecessary costs. Dairy breeds are large and late-maturing animals and carcass quality increases with increasing LW (Nogalski et al., 2014), so that dairy bulls could be an alternative for beef production because they have a higher weight gain capacity and can be slaughtered sooner (Vaz et al., 2001). Dairy bulls are more efficient and produce more lean meat than beef steers (Catrileo and Rojas, 2012). Nevertheless, to date there is no information on the quality and quantity of fat in Chilean dairy bulls. The objective of this work was to determine characteristic and quantity of fatty acids of the Longissimus thoracis of dairy bulls finished at pasture and in an intensive feeding system. 


\section{MATERIALS AND METHODS}

\section{Beef selection and sample preparation}

The study was carried out in La Araucanía Region, south Chile. Sixteen Holstein Friesian dairy bulls with an average age of 14-mo were studied at the Instituto de Investigaciones Agropecuarias, INIA Carillanca, Temuco (38 $41^{\prime}$ S, $72^{\circ} 25^{\prime} \mathrm{W}$; $200 \mathrm{~m}$ a.s.1.) The study was approved by INIA ethics/welfare committee confirming compliance with all requirements of the country for this type of animal experiments.

From 4 to $14-m o$ age the animals were managed by grazing. At the beginning of winter and after 10 -mo on pasture they were randomly divided into two treatments with eight bulls each. Forage diet treatment (FD): bulls with an average initial LW of $338.6 \pm 20 \mathrm{~kg}$ were fed by continuous grazing on 2 ha of mixed ryegrass (Lolium perenne L.) and clover (Trifolium repens L.), with additional free pasture silage of mixed ryegrass and clover, access to kale (Brassica oleracea L.) and concentrates at $1.0 \%$ of their LW. Kale was limited to $30 \%$ DM intake using electric fence. Concentrate diet treatment (CD): bulls with an average initial $341.3 \pm 17 \mathrm{~kg} \mathrm{LW}$ were kept together in a pen in a barn with the same silage pasture ad libitum and a daily amount of concentrate at $2 \% \mathrm{LW}$. The concentrate was the same for both groups and was composed of $65 \%$ triticale ( $\times$ Triticosecale spp.), $33 \%$ lupine (Lupinus luteus L.), $1 \%$ mineral salt and $1 \%$ sodium bicarbonate. The diet for both treatments were formulated approximately isoproteic for $14 \%$ crude protein and isoenergetic for $2.6 \mathrm{Mcal} \mathrm{ME} \mathrm{kg}{ }^{-1}$ to obtain maximum daily weight gains over $1.0 \mathrm{~kg}$ (AFRC, 1995).

The chemical content of feed samples was analyzed at the INIA Remehue Animal Nutrition and Environment Laboratory. Dry matter was measured by the method described by AOAC (1990). Crude protein was determined according to AOAC (1990) and metabolizable energy, ammoniacal $\mathrm{N}\left(\mathrm{N}-\mathrm{NH}_{3}\right), \mathrm{pH}$ and neutral detergent fiber according to Sadzawka et al. (2007). The chemical composition of feed is presented in Table 1.

There was a $14 \mathrm{~d}$ period before the experiment to accustom the animals to the two feeding system and management conditions. After this period animals were weighed at the beginning of the study at 14-mo age and every $14 \mathrm{~d}$ in the morning without fasting. The average

Table 1. Chemical composition of feeds used (DM basis).

\begin{tabular}{|c|c|c|c|c|c|c|}
\hline Feed & DM & $\mathrm{CP}$ & ME & NDF & $\mathrm{N}-\mathrm{NH}_{3}$ & $\mathrm{pH}$ \\
\hline & \multicolumn{2}{|c|}{$-\%$} & Mcal kg-1 & \multicolumn{2}{|c|}{$-\%$} & \\
\hline Pasture $^{1}$ & 31.5 & 11.2 & 2.36 & 60.2 & - & - \\
\hline Kale (Brassica olearacea L.) & 12.0 & 19.8 & 3.09 & 18.7 & - & - \\
\hline Pasture silage $^{2}$ & 34.2 & 20.1 & 1.83 & 47.9 & 10.5 & 4.2 \\
\hline Triticale ( $\times$ Triticosecale spp.) & 88.1 & 9.9 & 3.29 & 13.8 & - & - \\
\hline Lupine (Lupinus luteus L.) & 88.1 & 30.8 & 3.35 & 26.7 & - & - \\
\hline
\end{tabular}

DM: Dry matter; CP: crude protein; ME: metabolizable energy; NDF: neutral detergent fiber; $\mathrm{N}_{-} \mathrm{NH}_{3}$ : ammoniacal nitrogen.

${ }^{1}$ Mixed pasture of ryegrass (Lolium perenne) and clover (Trifolium repens).

${ }^{2}$ Silage of mixed pasture of ryegrass and clover. initial LW at 14-mo was $340 \mathrm{~kg}$ and the average final live weight at slaughter was $552 \pm 40 \mathrm{~kg}$ for the forage diet group and $549 \pm 20 \mathrm{~kg} \mathrm{LW}$ for the concentrate diet group, with $170 \mathrm{~d}$ and $147 \mathrm{~d}$ in the study, respectively. The animals were slaughtered according to industrial practice in Chile at a commercial slaughterhouse $20 \mathrm{~km}$ from INIA center. After slaughter, carcasses were identified and cooled for $24 \mathrm{~h}$ at $2{ }^{\circ} \mathrm{C}$. The $\mathrm{pH}_{24}$ ( $\mathrm{pH} 24 \mathrm{~h}$ post mortem) level was measured three times with a $\mathrm{pH}$ penetration electrode (Hanna FC232) of a portable pH-meter (Hanna 99163, Hanna Instruments, Woonsocket, Rhode Island, USA). In the quartering, $200 \mathrm{~g}$ of Longissimus thoracis was removed from the $8^{\text {th }}$ to the $9^{\text {th }}$ vertebra and transported to the meat science laboratory of the INIA Remehue. Muscle samples were vacuum packed and stored at $4 \pm 2{ }^{\circ} \mathrm{C}$ until analysis.

\section{Color and fat analysis}

Steaks were maintained for $30 \mathrm{~min}$ at room temperature prior to analysis. Instrumental color measurements were recorded for $L^{*}$ (lightness; 0: black, 100: white), $a^{*}$ (redness/greenness; positive values: red, negative values: green), and $b^{*}$ (yellowness/blueness; positive values: yellow, negative values: blue) using a Minolta chromameter (CR-400, Minolta, Osaka, Japan) with illuminat $\mathrm{D}_{65}$ and $2^{\circ}$ viewing angle. Readings were taken from three locations of the upper surface of randomly selected steaks to be representative of surface color. After color analysis, all external fat from steaks was removed and samples were ground and intramuscular fat (IMF) was measured by the Soxhlet extraction 920.39 method (AOAC, 1990). The rest of samples were vacuum-packed and stored at $-18 \pm 2{ }^{\circ} \mathrm{C}$ until fatty acid analysis.

\section{Fatty acid composition}

Fat was extracted according to Bligh and Dyer (1959) and Lumley and Colwell (1991). Briefly, $10 \mathrm{~g}$ fresh sample was thawed and fat extracted with methanol, chloroform, and water (40:25:16 mL). Samples were then homogenized for $30 \mathrm{~min}$ and passed through filter paper in a glass funnel. Water was added until biphasic separation was observed. The fat was concentrated in the chloroform layer. The chloroform phase was collected and removed by evaporation and $2.0 \mathrm{~mL}$ of $\mathrm{n}$-hexane was added to the extract, which was then stored at $-18 \pm 2{ }^{\circ} \mathrm{C}$ until analysis. Approximately $0.2 \mathrm{~g}$ fat was obtained with this extraction.

Transmethylation was carried out according to the method described by Ichihara et al. (1996). One hundred $\mu \mathrm{L}$ of $\mathrm{KOH}$ in 2-n methanol was added and the mixture (sample $+2.0 \mathrm{~mL}$ ) was agitated for $3 \mathrm{~min}$ at room temperature. After phase separation, the supernatant was collected and analyzed by gas chromatography. The fatty acid profile was determined in a gas chromatograph (GC-2010 plus Shimadzu, Kyoto, Japan) equipped with a flame ionization detector (FID). A capillary column SP2560 (Sigma-Aldrich, Bellefonte, Pennsylvania, USA) of 
$100 \mathrm{~m} \times 0.25 \mathrm{~mm} \times 0.25 \mu \mathrm{m}$ film was used. Helium was used as the carrier gas at $1.0 \mathrm{~mL} \mathrm{~min}^{-1}$ with an inlet pressure of 15 psi, using the split injection method (100:1). The injector temperature was fixed at $250{ }^{\circ} \mathrm{C}$ and the detector temperature at $260{ }^{\circ} \mathrm{C}$. The injected sample volume was $1.0 \mu \mathrm{L}$ and the oven temperature was programmed to increase from $140{ }^{\circ} \mathrm{C}$ (held for $5 \mathrm{~min}$ ) to $240{ }^{\circ} \mathrm{C}$ (held for $15 \mathrm{~min}$ ) at $4{ }^{\circ} \mathrm{C} \mathrm{min}^{-1}$. Fatty acids were identified by comparing the retention times of the chromatograph peaks to those of the methyl esters from a mixture prepared with a 37-component FAME mix standard (Standard: $47885-$ U, Sigma Aldrich, St. Louis, Missouri, USA), C18:1 $t$-11 methyl ester standard (Standard: 46905-U, Sigma Aldrich) and $c-9, t-11$ octadecadienoic conjugated methyl acid (Standard: 10-1823-7, Larodan AB, Malmo, Sweden).

\section{Experiment design and statistical analysis}

A completely randomized design was used with eight replicates (animals) per treatment. The results were submitted to an F-ANOVA test at 5\% significance, with the XLSTAT 2012 software package.

\section{RESULTS AND DISCUSSION}

Table 1 presents the chemical composition of the feed used in the study. As can be observed, the values are in consistent with the traditional nutrient content of local feeds for ruminants (Anrique et al., 2008).

Animal performance (Table 2) indicate that bulls with CD treatment reached a final weight of $549 \mathrm{~kg}$, while those on the forage diet reached a final weight of $552 \mathrm{~kg}$ 1-mo later at 21-mo of age and with 1.56 and $1.44 \mathrm{~kg}$ $a^{-1} \mathrm{~d}^{-1}$, respectively with no differences within treatments $(P>0.05)$. No significant differences were found for dressing percentage, rib eye area, and fat cover $(P>0.05)$. However, kidney fat of 4.44 and $2.61 \mathrm{~kg} \mathrm{an}^{-1}$, respectively, were significantly different for both treatments, as well as the $\mathrm{pH}_{24}(\mathrm{pH} 24 \mathrm{~h}$ post mortem), where the $\mathrm{CD}$ treatment presented a higher value (5.72) than the FD (5.46) $(P<$ $0.05)$. Higher levels of kidney fat have been observed in animals finished with concentrates as a consequence of higher levels of lipo enzyme activity (Smith and Crouse, 1984). Regarding pH, grass-fed beef tend to show higher

Table 2. Dairy bulls performance on finishing diets based on forage (FD) or concentrate diet (CD).

\begin{tabular}{|c|c|c|}
\hline & FD & $\mathrm{CD}$ \\
\hline Days on study & 170 & 147 \\
\hline Initial weight, $\mathrm{kg}$ & 338.6 & 341.3 \\
\hline Final weight, $\mathrm{kg}$ & 552.0 & 549.0 \\
\hline Daily live weight gain, $\mathrm{kg}$ animal ${ }^{-1}$ & 1.44 & 1.56 \\
\hline Carcass weight, $\mathrm{kg}$ animal $^{-1}$ & 295.8 & 293.2 \\
\hline Dressing percentage, $\%$ & 53.62 & 53.37 \\
\hline Rib eye area, $\mathrm{cm}^{2}$ & 75.74 & 76.74 \\
\hline Fat cover, $\mathrm{mm}$ & 1.19 & 1.44 \\
\hline Kidney fat, $\mathrm{kg}$ animal $^{-1}$ & $2.61 b$ & $4.44 \mathrm{a}$ \\
\hline $\mathrm{pH} 24 \mathrm{~h}$ post mortem & $5.46 \mathrm{~b}$ & $5.72 \mathrm{a}$ \\
\hline
\end{tabular}

Letter within a row indicates difference $(P<0.05)$.

$\mathrm{CD}$ : concentrate based diet; FD: forage based diet.
$\mathrm{pH}_{24}$ than animals grain-fed beef (French et al., 2001; Del Campo et al., 2008), which could be related to higher levels of muscle glycogen content in animals fed with high-energy diets (Del Campo et al., 2008). However, the $\mathrm{pH}_{24}$ value of the animals in the CD treatment is lower than those observed in the study of Catrileo and Rojas (2012) under similar conditions. This could be associated with the confined being more active despite the balanced diet they received.

The percentage of intramuscular fat (IMF) was significantly higher $(P<0.05)$ for the CD treatment (Table 3). However, levels are lower than those reported in the same muscle by Morales et al. (2012) $(2.1 \%$ and $2.3 \%$ lower), which could be associated with higher rates of daily weight gain of bulls on a concentrate diet. In this respect, Padre et al. (2006) observed a higher lipid content in steers than in bulls. The lower IMF content in bull beef is due to the presence of testosterone, which is associated with the greater capacity for muscle growth in bulls (Field, 1971).

Colour ( $L^{*}$ parameter) differences were found that could be related to the higher $\mathrm{pH}$ values for the $\mathrm{CD}$ treatment. This in turn could be because bulls in the feedlot (barn), in spite of a diet higher in carbohydrate, were more active (due to unfamiliar surroundings) than the bulls on the forage diet in the field, which caused a higher incidence of dark cutting. On the other hand, several studies indicate that grass-fed beef is darker than beef from grain-finished animals (Realini et al., 2004), because pasture-fed animals have more muscle myoglobin since they are more active than concentrate-fed animals that are kept indoors (Priolo et al., 2001).

\section{Longissimus thoracis intramuscular fatty acid composition}

Intramuscular fat from the FD treatment had higher levels $(P<0.05)$ of C14:0, C15:0, C18:0, C20:0, and C22:0 and all saturated fatty acids (SFA), in meat than CD with no differences between treatments in C16:0 and C17:0 fatty acids (Table 4). Total monounsaturated fatty acid (MUFA), oleic acid (C18:1 c-9), C16:1 and C17:1 levels were higher in IMF from the CD treatment than from the FD (Table 4). No differences $(P>0.05)$ were found for C14:1, C18:1 n-7, and C18:1 $t$-11.

The percentage of all polyunsaturated fatty acids, PUFA, C18:2 n-6 trans, C18:3 n-3, C22:5 n-3, C22:6 n-3,

Table 3. Intramuscular fat (IMF) content (\%), pH, and color of Longissimus thoracis muscle of dairy bulls on two feeding systems.

\begin{tabular}{lccc}
\hline Parameters & CD & FD & RMSE \\
\hline IMF & $1.94 \mathrm{a}$ & $0.90 \mathrm{~b}$ & 0.903 \\
$L^{*}$ & $39.90 \mathrm{a}$ & $35.93 \mathrm{~b}$ & 3.506 \\
$a^{*}$ & 19.97 & 21.28 & 2.533 \\
$b^{*}$ & 10.30 & 10.34 & 2.288 \\
\hline
\end{tabular}

Different letter within a row indicates significant difference $(P<0.05)$. $\mathrm{CD}$ : concentrate based diet; FD: forage based diet; RMSE: root mean squared error. IMF: intramuscular fat ; $L^{*}$, (lightness; 0: black, 100: white); $a^{*}$ (redness/ greenness; positive values: red, negative values: green); $b^{*}$ (yellowness/ blueness; positive values: yellow, negative values: blue). 
Table 4. Means for fatty acid composition (\%) of Longissimus thoracis of dairy bulls on two feeding systems.

\begin{tabular}{|c|c|c|c|}
\hline Fatty acid & $\mathrm{CD}$ & FD & RMSE \\
\hline C $14: 0$ & $2.78 b$ & $4.65 \mathrm{a}$ & 1.301 \\
\hline C $14: 1$ & 0.48 & 0.38 & 0.169 \\
\hline C 15:0 & $0.32 \mathrm{~b}$ & $0.70 \mathrm{a}$ & 0.174 \\
\hline C $16: 0$ & 26.93 & 25.73 & 1.685 \\
\hline C $16: 1$ & $2.84 \mathrm{a}$ & $1.34 \mathrm{~b}$ & 0.442 \\
\hline C 17:0 & 1.04 & 0.93 & 0.144 \\
\hline C $17: 1$ & $0.76 \mathrm{a}$ & $0.36 \mathrm{~b}$ & 0.175 \\
\hline C $18: 0$ & $14.83 b$ & $18.53 \mathrm{a}$ & 1.654 \\
\hline C $18: 1 n-11$ trans & 2.58 & 2.09 & 1.175 \\
\hline C $18: 1 n-9$ cis & $35.00 \mathrm{a}$ & $26.38 b$ & 4.365 \\
\hline C $18: 1 n-7$ & 0.81 & 0.66 & 0.447 \\
\hline C $18: 2 n-6 c i s$ & 6.96 & 9.23 & 2.314 \\
\hline C $18: 2 n-6$ trans & $0.06 \mathrm{~b}$ & $0.22 \mathrm{a}$ & 0.033 \\
\hline C 20 & $0.05 b$ & $0.13 \mathrm{a}$ & 0.065 \\
\hline C $18: 3 n-3$ & $1.35 \mathrm{~b}$ & $3.25 \mathrm{a}$ & 0.645 \\
\hline C 18:2 n-6 CLA 9 cis 11 trans & $0.30 \mathrm{~b}$ & $0.58 \mathrm{a}$ & 0.131 \\
\hline C 22:0 & $0.04 \mathrm{~b}$ & $0.19 \mathrm{a}$ & 0.051 \\
\hline C $20: 3 n-6$ & 0.37 & 0.50 & 0.202 \\
\hline C $20: 3 n-3$ & 0.10 & 0.25 & 0.245 \\
\hline C 20:4 n-6 & 1.62 & 2.40 & 0.953 \\
\hline C 22:2 & 0.03 & 0.12 & 0.089 \\
\hline C $20: 5 n-3$ & $0.06 \mathrm{~b}$ & $0.19 \mathrm{a}$ & 0.104 \\
\hline C $22: 5 n-3$ & $0.61 b$ & $1.25 \mathrm{a}$ & 0.444 \\
\hline C $22: 6 n-3$ & 0.04 & 0.02 & 0.052 \\
\hline SFA & $45.99 \mathrm{~b}$ & $50.85 \mathrm{a}$ & 2.877 \\
\hline MUFA & $42.46 \mathrm{a}$ & $31.20 \mathrm{~b}$ & 4.657 \\
\hline PUFA & $11.49 \mathrm{~b}$ & $18.00 \mathrm{a}$ & 4.598 \\
\hline$n-3$ & $2.16 \mathrm{~b}$ & $4.96 \mathrm{a}$ & 1.269 \\
\hline$n-6$ & 9.30 & 12.93 & 3.425 \\
\hline P:S & 0.25 & 0.36 & 0.105 \\
\hline$n-6: n-3$ & $4.54 \mathrm{a}$ & $2.64 b$ & 0.638 \\
\hline
\end{tabular}

Different letter within a row indicates significant difference $(P<0.05)$.

CD: concentrated based diet; FD: forage based diet; RMSE: root mean squared error; CLA: conjugated linoleic acid; SFA: saturated fatty acids: $\mathrm{C} 14: 0+\mathrm{C} 16: 0+\mathrm{C} 17: 0+\mathrm{C} 18: 0+\mathrm{C} 20: 0+\mathrm{C} 22: 0 ;$ MUFA: monounsaturated fatty acids: C16:1 + C17:1 + C18:1 n-9 + C18:1 n-7 + C18:1 n-11; PUFA: polyunsaturated fatty acids: $\mathrm{C} 18: 2 n-6+\mathrm{C} 18: 2 n-6$ trans $+\mathrm{C} 18: 3 n-3+\mathrm{C} 20: 3$ $n-6+\mathrm{C} 20: 3 n-3+\mathrm{C} 20: 4 n-6+\mathrm{C} 20: 5 n-3 ; \mathrm{C} 22: 5 n-3+\mathrm{C} 22: 6 n-3+$ CLA c-9 t-11; PS: polyunsaturated:saturated fatty acid ratio; $n-6: n-3$ : fatty acid ratio.

were significantly higher $(P<0.05)$ for the FD treatment than the CD. The percentages of all PUFAs were higher than those reported in Chilean studies with steers (Morales et al., 2012) and other studies using different animal feed sources (Schor et al., 2008), although similar to those for Holstein Friesian bulls according to Padre et al. (2006).

Although seafood is the major dietary source of $n-3$ fatty acids, red meat also constitutes a significant source for some populations with limited consumption of seafood (Sinclair et al., 1994). In the present study, the pasture-fed beef had higher 18:3n-3 and all $n-3$ fatty acid values.

C18:1 $t$-11 (trans-vaccenic acid) levels were similar between the two treatments and similar to levels found in others studies with steers fed on pasture plus supplements and feedlot. Some studies suggest a linear increase in CLA $c-9, t-11$ synthesis as the C18:1 $t$-11 content of the diet increases in human subjects (Salminen et al., 1998; Turpeinen et al., 2002), while the C18:1 $t-11$ to CLA $c-9$, $t-11$ conversion rate is estimated at $5 \%$ to $12 \%$ in rodents and $19 \%$ to $30 \%$ in humans (Turpeinen et al., 2002).

Conjugated linoleic acid $c-9, t-11$ was higher $(P<0.05)$ for the FD treatment. CLA $c-9, t-11$ is produced as a result of biohydrogenation in the rumen, where unsaturated fatty acids (mainly C18:2 $n-6$ and C18:3n-3) from the diet are isomerized and then partially saturated (De La Torre et al., 2006). CLA $c-9, t-11$ is also synthesized by endogenous conversion of C18:1 $t$-11 (trans-vaccenic acid) by the enzyme $\Delta$-9-desaturase in adipose tissue and the mammary gland (Bauman et al., 2011). Biohydrogenation is affected by the level of concentrates in the animal diet (Scollan et al., 2014) and the CLA $c-9, t-11$ concentration in the adipose tissue is higher when animals are fed on pasture than on stored forage or grain (French et al., 2000). Other studies have also shown that steers finished on pasture have higher CLA $c-9, t-11$ than those fed on grain-based diets (Realini et al., 2004; Del Campo et al., 2008; De la Fuente et al., 2009; Morales et al., 2012).

There were no differences between the treatments in the P:S ratio of IMF $(P>0.05)$. A value of 0.4 or higher is recommended for the P:S ratio (British Department of Health, 1994). However, De la Fuente et al. (2009) indicated that the P:S ratio has limited significance because not all saturated fatty acids increase cholesterol. Moreover, the positive effect of monounsaturated fatty acids such as C18:1 c-9 (Lee et al., 1998) for human health is not considered when this ratio is used. C18:1 c-9 increases human HDL (high-density lipoprotein)cholesterol and decreases LDL (low-density lipoprotein)cholesterol concentrations (Katan et al., 1994), and there is a positive relationship between LDL-cholesterol levels and human cardiovascular diseases. In contrast, HDLcholesterol reduces the risk of cardiovascular diseases (Kwiterovich, 1997).

Considerable attention has been paid to the relative proportion of $n-6$ and $n-3$ fatty acids, as diets with high $n-6: n-3$ ratios have been highlighted as risk factors for certain cancers and coronary heart diseases (Hibbeln et al., 2006). A value of 4.0 or less for a diet is recommended for the $n-6: n-3$ ratio (British Department of Health, 1994).

Beef from the FD treatment had $n-6: n-3$ ratios below 4.0 (Table 4), which is consistent of other studies (Schor et al., 2008; De la Fuente et al., 2009; Klee et al., 2011; Morales et al., 2012). These authors also found that the $n$-6: $n$-3 ratio increases as the grain or concentrate content in the diet increases.

\section{CONCLUSIONS}

Under the conditions of the present study dairy bulls fed the forage diet had higher levels of all polyunsaturated fatty acids, including conjugated linoleic acid, than the bulls fed the concentrate diet. There were no differences in final live weight, dressing percentage, daily weight gain, rib eye area and fat cover, although finishing required one month less with the concentrate-fed bulls.

\section{ACKNOWLEDGEMENTS}

The authors wish to thanks to the Instituto de Investigaciones Agropecuarias (INIA) research fund to 
support this study and Frigorífico Temuco S.A. for its collaboration and technical support.

\section{LITERATURE CITED}

AFRC. 1995. Energy and protein requirements of ruminants: An advisory manual. 159 p. Agriculture and Food Research Council (AFRC) Technical Committee on Responses to Nutrients. CAB International, Wallingford, Oxon, UK.

Anrique, R., P. Fuchslocker, S. Iraira, y P. Saldaña. 2008. Composición de alimentos para el ganado bovino. $3^{\mathrm{a}}$ ed. $87 \mathrm{p}$ Universidad Austral de Chile, Consorcio Lechero, Instituto de Investigaciones Agropecuarias INIA, Valdivia, Chile.

AOAC. 1990. Official methods of analysis of the Association of Official Analytical Chemists. 15 ed. Vol. II. 1298 p. Association of Official Analytical Chemists (AOAC), Arlington, Virginia, USA.

Banni, S., E. Muuru, E. Angioni, G. Carta, and M.P. Melis. 2002. Conjugated linoleic acid isomers (CLA): Good for everything? Science Aliments 22:371-380.

Bauman, D.E., K.J. Harvatine, and A.L. Lock. 2011 . Nutrigenomics, rumen-derived bioactive fatty acids, and the regulation of milk fat synthesis. Annual Review of Nutrition 31:299-319.

Bligh, E.G., and W.J. Dyer. 1959. A rapid method of total lipid extraction and purification. Canadian Journal of Biochemistry and Physiology 37:911-917.

British Department of Health. 1994. Nutritional aspects of cardiovascular disease. Report on Health and Social Subjects $\mathrm{N}^{\circ}$ 46. Her Majesty's Stationery Office (HMSO), The National Archives, London, UK.

Catrileo, A., and C. Rojas. 2012. A beef production system from dairy bulls under pasture in the south of Chile. Chilean Journal Agricultural and Animal Science 28:41-50.

De la Fuente, J., M.T. Díaz, I. Álvarez, M.A. Oliver, M. Font i Furnols, and C. Sañudo. 2009. Fatty acid and vitamin E composition of intramuscular fat in cattle reared in different production systems. Meat Science 82:331-337.

De La Torre, A., D. Gruffat, D. Durand, D. Micol, A. Peyron, V. Scislowski, et al. 2006. Factors influencing proportion and composition of CLA in beef. Meat Science 73:258-268.

Del Campo, M., G. Brito, J.M.S. de Lima, D.V. Martins, C. Sañudo, R.S. Julián, et al. 2008. Effects of feeding strategies including different proportion of pasture and concentrate, on carcass and meat quality traits in Uruguayan steers. Meat Science 80:753-760.

Field, R.A. 1971. Effect of castration on meat quality and quantity. Journal of Animal Science 32:849-857.

French, P., E.G.O. Riordan, P.O. Kiely, P.J. Caffrey, and A.P. Moloney. 2001. Intake and growth of steers offered different allowances of autumn. Animal Science 72:129-138.

French, P., C. Stanton, F. Lawless, E.G. O'Riordan, F. Monahan, P.J. Caffrey, et al. 2000. Fatty acid composition, including conjugated linoleic acid, of intramuscular fat from steers offered grazed grass, grass silage or concentrate based diets. Journal of Animal Science 78:2849-2855.

Hibbeln, J.R., L.R. Nieminen, T.L. Blasbalg, J.A. Riggs, and W.E. Lands. 2006. Healthy intakes of n-3 and n-6 fatty acids: estimations considering worldwide diversity. American Journal Clinical Nutrition 83:1483-1493.

Ichihara, K., A. Shibahara, K. Yamamoto, and T. Nakayama. 1996. An improved method for rapid analysis of the fatty acids of glycerolipids. Lipids 31:535-539.

Johnson, A. 2009. The role of red meat in a healthy New Zealand diet. 26 p. Beef and Lamb New Zealand, Takapuna, Auckland, New Zealand.

Katan, M.B., P.L. Zock, and R.P. Mesink. 1994. Effects of fats and fatty acid on blood lipids in humans: An overview. American Journal of Clinical Nutrition 60(suppl. 1):1017-1022.

Klee, G., N. Mendoza, and J. Chavarría. 2011. Production and meat fatty acids profile of Hereford steers fed on pasture with and without oat grain supplement. Chile, VIII Región. Ciencia e Investigación Agraria 38:331-338
Kwiterovich, P.O. 1997. The effect of dietary fat, antioxidants and pro-oxidants on blood lipids, lipoproteins and atherosclerosis. Journal of American Dietetic Association 97(supplement):31-41.

Lee, K.N., M.W. Pariza, and J.M. Ntambi. 1998. Conjugated linoleic acid decreases hepatic stearoyl-CoA desaturase mRNA expression. Biochemical Biophysical Research Communications 248:817-821.

Lumley, I.D., and R.K. Colwell. 1991. Extraction of fats from fatty foods and determination of fat content. p. 227-245. In Rossell, J.B., and J.L.R. Pritchard (eds.) Analysis of oilseeds, fats and fatty foods. Elsevier Applied Science, London, UK

Morales, R., A.P.S. Aguiar, I. Subiabre, and C. Realini. 2013. Beef acceptability and consumer expectations associated with production systems and marbling. Food Quality and Preference 29:166-173.

Morales, R., C. Folch, S. Iraira, N. Teuber, and C. Realini. 2012 Nutritional quality of beef produced in Chile form different production systems. Chilean Journal of Agricultural Research 72:80-86.

Nogalski, Z., Z. Wielgosz-Groth, C. Purwin, A. Nogalska, M Sobczuk-Szul, R. Winarski, et al. 2014. The effect of slaughter weight and fattening intensity on changes in carcass fatness in young Holstein-Friesian bulls. Italian Journal of Animal Science 13:66-72.

Padre, R.G., J.A. Aricetti, F.B. Moreira, I.Y. Mizubitu, I.N Prado, and J. Visentainer. 2006. Fatty acid profile and chemical composition of Longissimus muscle of bovine steers and bulls finished in pasture system. Meat Science 74:242-248.

Pereira, P.M.D.C.C., and A.F.D.R.B. Vicente. 2013. Meat nutritional composition and nutritive role in the human diet. Meat Science 93:586-592.

Priolo, A., D. Micol, and J. Agabriel. 2001. Effects of grass feeding systems on ruminant meat colour and flavour. A review. Animal Research 50:185-200.

Realini, C.E., S.K. Duckett, G.W. Brito, M. DallaRizza, and D De Mattos. D. 2004. Effect of pasture vs. concentrate feeding with or without antioxidants on carcass characteristics, fatty acid composition, and quality of Uruguayan beef. Meat Science 66:567-577.

Sadzawka, A., M. Carrasco, R. Demanet, H. Flores, R. Grez, M Mora, et al. 2007. Métodos de análisis de tejidos vegetales. 140 p. Serie Actas $\mathrm{N}^{\circ}$ 40. Instituto de Investigaciones Agropecuarias, Santiago, Chile.

Salminen, M.M., M. Mutanen, M. Jauhiainen, and A. Aro. 1998 Dietary trans-fatty acids increase conjugated linoleic acid levels in human serum. Journal Nutrition Biochemistry 9:93-98.

Schmid, A., M. Collomb, R. Sieber, and G. Bee. 2006. Conjugated linoleic acid in meat and meat products: A review. Meat Science 73:29-41.

Schor, A., M.E. Cossu, A. Picallo, J. Martínez Ferrer, J.J. Grigera Naón, and D. Colombatto. 2008. Nutritional and eating quality of Argentinian beef: A review. Meat Science 79:408-422.

Scollan, N.D., D. Dannenberger, K. Nuernberg, I. Richardson, S Mackintosh, J.-F. Hocquette, et al. 2014. Enhancing the nutritional and health value of beef lipids and their relationship with meat quality. Meat Science 97:384-394.

Sinclair, A.J., L. Johnson, K. O’Dea, and R.T. Holman. 1994. Diet rich in lean beef increase arachidonic acid and long-chain omega 3 polyunsaturated fatty acids levels in plasma phospholipids. Lipids 29:337-343.

Smith, S.B., and J.D. Crouse. 1984. Relative contributions of acetate, lactate and glucose to lipogenesis in bovine intramuscular and subcutaneous adipose tissue. Journal of Nutrition 114:792-800.

Turpeinen, A.M., M. Mutanen, I. Salminen, S. Basu, D.L. Palmquist, and J.M. Griinari. 2002. Bioconversion of vaccenic acid to conjugated linoleic acid in humans. American Journal of Clinical Nutrition 76:504-510.

Vaz, F.N., J. Restle, G.L.D. Feijó, I.L. Brondani, J.R. Rosa, and A.P. Santos. 2001. Quality and composition of meat from entire or castrated beef cattle from different Charolais $\times$ Nellore genetic groups. Revista Brasileira de Zootecnia 30:518-525. 